\title{
Techno-Economic Analysis of Biomass Energy Utilization through Gasification Technology for Sustainable Energy Production and Economic Development in Nigeria
}

\author{
Gbeminiyi M. Sobamowo $(\mathbb{D})$ and Sunday J. Ojolo \\ Department of Mechanical Engineering, University of Lagos, Akoka, Nigeria \\ Correspondence should be addressed to Gbeminiyi M. Sobamowo; mikegbeminiyi@gmail.com
}

Received 10 March 2018; Revised 4 September 2018; Accepted 27 September 2018; Published 18 October 2018

Academic Editor: Makarand M. Ghangrekar

Copyright (C) 2018 Gbeminiyi M. Sobamowo and Sunday J. Ojolo. This is an open access article distributed under the Creative Commons Attribution License, which permits unrestricted use, distribution, and reproduction in any medium, provided the original work is properly cited.

\begin{abstract}
Nigeria has not been able to provide enough electric power to her about 200 million people. The last effort by the federal government to generate $6000 \mathrm{MW}$ power by the end of 2009 failed. Even with the available less than $6000 \mathrm{MW}$ of electricity generated in the country, only about $40 \%$ of the population have access to the electricity from the National Grid, out of which, urban centers have more than $80 \%$ accessibility while rural areas, which constitute about $70 \%$ of the total population, have less than $20 \%$ of accessibility to electricity. This paper addresses the possibility of meeting the energy demand in Nigeria through biomass gasification technology. The techno-economic analysis of biomass energy is demonstrated and the advantages of the biomass gasification technology are presented. Following the technical analysis, Nigeria is projected to have total potential of biomass of about 5.5 EJ in 2020 which has been forecast to increase to about 29.8 EJ by 2050 . Based on a planned selling price of $\$ 0.727 / \mathrm{kWh}$, the net present value of the project was found to be positive, the cost benefit ratio is greater than 1, and the payback period of the project is 10.14 years. These economic indicators established the economic viability of the project at the given cost. However, economic analysis shows a selling price of $\$ 0.727 / \mathrm{kWh}$. Therefore, the capital investment cost, operation and maintenance cost, and fuel cost can be reduced through the development of the gasification system using local materials, purposeful and efficient plantation of biomass for the energy generation, giving out of financial incentives by the government to the investors, and locating the power plant very close to the source of feedstock generation.
\end{abstract}

\section{Introduction}

The ever increasing energy demands, dwindling sources of fossil fuels, and concern about pollution levels in the environment have been the major concerns of Nigeria government. There are persistence failure of continuous power production and low performance of Nigeria electricity generation sector. Such odious occurrences can be attributed to high rates of transmission losses, low rate of generation capacity (Table 1), and poor revenue collection in meeting energy demands in Nigeria. Consequently, different alternative means of electricity generation have been sought of which more than $70 \%$ of the electricity in the country is generated from fossil fuels. Adversely, the green house emission from such fuels is high; approximately one-third of the national emission results from electricity production. Also, the transport systems majorly rely on the fossil fuels. Indisputably, the prices of the fossil fuels are subject to fluctuations and the end users have little or no control. The overdependence on the fossil fuels has resulted in a rapid decrease in the high grade energy source.

Nigeria depends majorly on her large crude oil reserve which is less than 40 billion barrels of oil. Not long ago, the production of crude oil has also been estimated to be about 2.2 million barrels per day. Most of these are exported while 280 thousand barrels of oil are refined per day for consumption within the country. Energy Information Administration (EIA) [1] reports that the natural gas proven reserve is estimated to be about 185 trillion cubic feet. In 2008, Nigeria consumed about 430 billion cubic feet mostly for electricity generation. 140 billion cubic feet was vented, 530 billion cubic feet was flared, and about 500 billion cubic feet was reinjected for enhanced oil recovery. The gross annual 
TABLE 1: Electrical generation and consumption in Nigeria.

\begin{tabular}{lccc}
\hline Year Installed & $\begin{array}{c}\text { Capacity } \\
(\text { MW })\end{array}$ & Total Generation & Capacity Utilized (\%) \\
\hline 1990 & 4548.0 & 1536.9 & 33.8 \\
1991 & 4548.0 & 1647.2 & 35.6 \\
1992 & 4548.0 & 1693.4 & 37.0 \\
1993 & 4548.6 & 1655.8 & 36.4 \\
1994 & 4548.6 & 1772.9 & 39.0 \\
1995 & 4548.6 & 1810.1 & 39.8 \\
1996 & 4548.6 & 1854.2 & 40.8 \\
1997 & 4548.6 & 1839.8 & 40.4 \\
1998 & 4538.6 & 1724.9 & 37.9 \\
1999 & 5580.0 & 1859.8 & 33.3 \\
2000 & 5580.0 & 1738.3 & 31.2 \\
2001 & 6180.0 & 1689.9 & 27.5 \\
2002 & 6180.0 & 2237.3 & 36.2 \\
2003 & 6130.0 & 2378.4 & 38.8 \\
2004 & 6130.0 & 2763.6 & 45.1 \\
2005 & 6538.3 & 2494.4 & 40.5 \\
\hline
\end{tabular}

Source: National Electric Power Authority [6].

consumption of natural gas is put at 1,600 billion cubic feet. The recoverable coal reserves are estimated to be about 210 million short tons with the production being 9 thousand short tons per annum and consumption being about 12 thousand short tons per annum [1]. On the assumption that new oil or gas reserves are not discovered, it is estimated that the crude oil reserves in Nigeria should run out within the next 50 years and the proven natural gas reserves should run out in about 115 years. Following the past reports and the projected energy demands in Nigeria as shown in Figure 1, it is established that Nigeria crude oil reserves will soon dry up. An August 5, 2001, British Petroleum report indicates that the 22-billion-barrel Nigeria oil reserves in year 2001 would be exhausted in 29 years if the production level is maintained. More than 2\% annual decline was recorded from 2002 to 2007 [2]. According to the report of energy officials for Africa's largest oil producer, it was stated that Nigeria's oil reserves (which increased to 32.93 billion barrels, 2008) could dry up in the next 50 years.

Furthermore, considering the prices of the fossil fuel, it is becoming clear to both Nigeria government and the consumers that energy prices in general are now likely to stay higher for longer period of time. Following the rising political awareness of global climate change and the rising concern over energy import dependence, many consuming nation governments are looking to develop more coherent policies on alternative energy. Indubitably, alternative energy has provided a potential fix for rising carbon emissions and energy insecurity for many years, but at a price that was deemed unacceptably high versus the prevailing price of traditional energy sources (oil, gas, and coal). Low oil prices kept most alternative energy technologies dormant for much of the period 1986-2002. Now with the continuous increase in crude oil prices coupled with the fact that some jurisdictions already attempting to ascribe a cost to

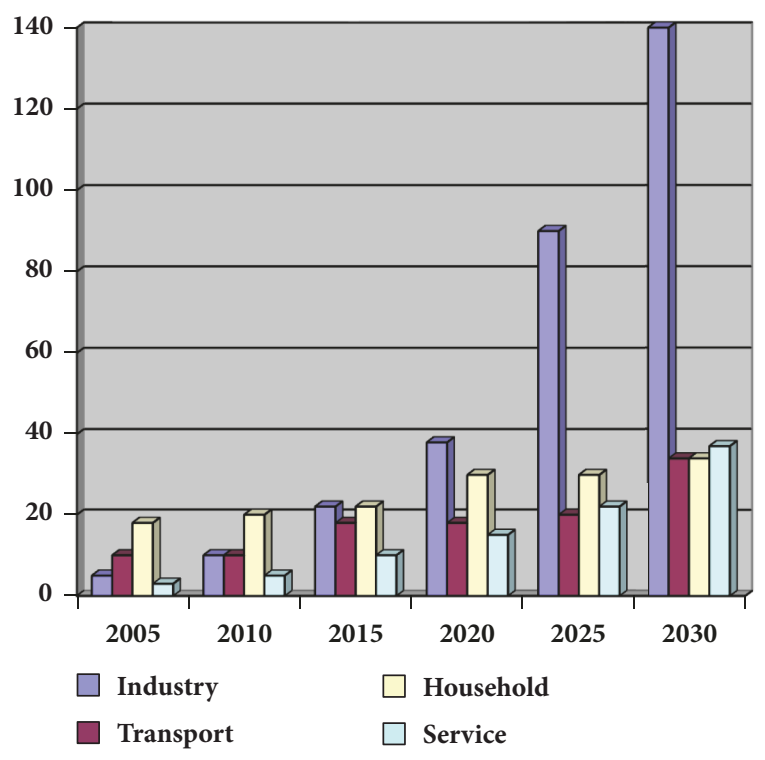

FIGURE 1: Nigeria predicted energy consumption growth.

carbon emission, the outlook for certain forms of alternative energy is vastly improved. Additionally, seeking for a balance between energy, economy, and environment has been the trilemma threatening the human survival not only in Nigeria but in the world at large.

\section{The Plan for Alternative Energy Resources}

The alarming increase in Nigeria's population has consequently increased the energy demands exponentially. Also, there is persistent increase in the threats on human health and environment as a result of carbon emissions for the 
TABLE 2: Total projected energy demand (MTOE).

\begin{tabular}{lcccccc}
\hline Scenario & $\mathbf{2 0 0 0}$ & $\mathbf{2 0 1 0}$ & $\mathbf{2 0 1 5}$ & $\mathbf{2 0 2 0}$ & $\mathbf{2 0 2 5}$ & $\mathbf{2 0 3 0}$ \\
\hline Reference (7\%) & 32.01 & 51.40 & 79.36 & 118.14 & 169.18 & 245.19 \\
High growth (10\%) & 32.01 & 56.18 & 94.18 & 190.7 & 256.19 & 414.52 \\
Optimistic (11.5\%) & 32.01 & 56.18 & 108.57 & 245.97 & 331.32 \\
Optimistic (13\%) & 32.01 & 72.81 & 148.97 & 312.61 & 426.11 & 715.70 \\
\hline
\end{tabular}

Source: Adapted from ECN [7].

combustion of fossil fuels. Furthermore, the continuous increasing energy demands and incessant decreases in the high grade energy source have paved way for the utilization of different alternative energy sources. Such sustainable energy means have provided a potential fix for rising carbon emissions and energy insecurity for many years. Additionally, in order to overcome the trilemma of achieving economic growth, food supply, and energy resources, while conserving the environment, the federal government of Nigeria has developed long-term "energy descent" through Energy Commission of Nigeria (ECN). These are designed for gradual reduction in the overdependence on high grade energy and switching to local renewable energy resources (solar, wind, wave, biomass, geothermal, ocean and tidal, hydrothermal, etc.) as part of local economies. Laying a solid foundation for the potentials of the renewable energy sources, it is established that Nigeria occupies a total land area of 92,337, $000 \mathrm{ha}\left(923,370 \mathrm{~km}^{2}\right)$ of which $30,200,000$ ha is arable land, $2,800,000$ ha is used for permanent crops, 39, 200, 000 ha is used for permanent pasture, $14,300,000$ ha is forests and woodlands, and 5,837,000 ha is used for other purposes [5]. In this milieu, there is no doubt that the country has adequate potential of renewable energy sources especially for biomass production and therefore, bioenergy should be considered as an important part of a future renewable energy mix in the country. Consequently, there is a need to harness this huge energy potential by employing the various biomass technologies and formulating policies to the effect. There is also a need to enhance the development of the agricultural subsector of the economy since biomass is agriculturally generated.

\section{The Possibility of Meeting Nigeria Energy Needs Using Bioenergy}

It is notoriously difficult to forecast long-term energy demand. However, the need for energy demand projection for short-term plans is indispensable. Following the models developed by Energy Commission of Nigeria (ECN) [7], the country's energy demand was analyzed for the period of 2000 to 2030 with the use of the Model for the Analysis of Energy Demand (MAED) and Wien Automatic System Planning (WASP) packages (Table 2). From the table, it seems clear that the energy demand continues to grow. One of the unparalleled solutions to meet the accelerated growth in the energy demand is to lay the foundation for accelerated renewable energy development that will sustain the economic.
According to European Commission in the white papers' community strategy and action plan in the policies of the European Union [11], biomass is expected to play a major role as a renewable energy source. The development of biomass gasification plant for energy generation is seen as a means of enhancing the environment acceptability of agricultural wastes as sources of energy as well as of increasing the overall efficiency of the conversion of the chemical energy in the wastes into electricity. The abundant possession of biomass in Nigeria as pointed out in literatures proved beyond measures on the sustainability of the various biomass technologies in Nigeria. According to the study carried out by Ojolo and Orisaleye [11], Nigeria has a large biomass potential estimated to be at least 3.2 EJ in 2010 and this could abundantly satisfy the energy demand in the country. The biomass sources considered are agro-residues, livestock wastes, municipal solid wastes, and forest residues. The energy potential is expected to continue to grow from about $3.2 \mathrm{EJ}$ in 2010 to about $5.5 \mathrm{EJ}$ in 2020 and may reach about $29.8 \mathrm{EJ}$ in 2050 . The estimate compares well with forecasted energy demand and will play a great role in future energy supply. The delay in the utilization of the renewable energy is due to the government policy formulations which have not favoured the development of biomass technologies for efficient utilization of biomass. However, in 2012, the federal government reconsidered their plans and set out to have the first biomass gasification plant in Ekiti State. Before the full implementation of the policy, there is a need to consider the technical and the economic potential of biomass energy and biomass gasification technology in the country. Therefore, this study presents the techno-economic potentials of the biomass gasification technology in Nigeria.

\section{Technical Potential of Biomass Energy in Nigeria}

Agriculture, being the dominant economic activity in Nigeria, contributes $41 \%$ of the GDP and employs the highest labour in the country [12]. Although the priority of the agricultural policy of Nigeria government is food production, the potential solid fuels for power generation that accompany the agricultural activities in the country is quite enormous. Following the recent report of Aurela [13], about 43.4 billion $\mathrm{kg}$ of fuelwood is consumed annually in Nigeria while 1.8 million tons of sawdust is produced annually. Also, Ojolo and Orisaleye [14] pointed out that the total estimate for energy potential of agro-residues obtained in Nigeria in 2005 is $1.924 \times 10^{18} \mathrm{~J}$. In order to establish the technical potential 
TABLE 3: Energy potential of foreign residues in Nigeria (1997).

\begin{tabular}{lcccccc}
\hline & \multicolumn{3}{c}{ Full Capacity } & & \multicolumn{2}{c}{ Capacity utilized } \\
\hline Forest Residue & $\begin{array}{c}\text { Volume } \\
\left(\mathrm{m}^{3}\right)\end{array}$ & $\begin{array}{c}\text { Mass } \\
(\text { '000 tonnes })\end{array}$ & $\begin{array}{c}\text { Energy derivable } \\
\left(10^{15} \mathrm{~J}\right)\end{array}$ & $\begin{array}{c}\text { Volume } \\
\left(\mathrm{m}^{3}\right)\end{array}$ & $\begin{array}{c}\text { Mass } \\
\left({ }^{3} 000 \text { tonnes }\right)\end{array}$ & $\begin{array}{c}\text { Energy derivable } \\
\left(10^{15} \mathrm{~J}\right)\end{array}$ \\
\hline Sawdust & 463,580 & 185.4 & 2.7 & 200,000 & 80 & 1.2 \\
Wood chips & $1,390,740$ & 403.3 & 5.6 & 600,000 & 174 & 2.4 \\
\hline TOTAL & & & $\mathbf{8 . 3}$ & & \\
\hline
\end{tabular}

TABLE 4: 5-yearly estimate energy potential of agro-residues through 2050.

\begin{tabular}{lcccccccccc}
\hline Year & $\mathbf{2 0 0 5}$ & $\mathbf{2 0 1 0}$ & $\mathbf{2 0 1 5}$ & $\mathbf{2 0 2 0}$ & $\mathbf{2 0 2 5}$ & $\mathbf{2 0 3 0}$ & $\mathbf{2 0 5 5}$ & $\mathbf{2 0 4 0}$ & $\mathbf{2 0 4 5}$ & $\mathbf{2 0 5 0}$ \\
\hline Energy potential of residue $(\mathrm{P}))$ & 1924.2 & 2575 & 3445.9 & 4611.5 & 6171.2 & 8258.4 & 11051.6 & 14789.6 & 19791.8 & 26485.9 \\
\hline
\end{tabular}

TABLE 5: 5-yearly potential of forest residues at $5.5 \%$ increase in production rate $\left(10^{15} \mathrm{~J}\right)$.

\begin{tabular}{lcccccccccc}
\hline Year & $\mathbf{2 0 0 5}$ & $\mathbf{2 0 1 0}$ & $\mathbf{2 0 1 5}$ & $\mathbf{2 0 2 0}$ & $\mathbf{2 0 2 5}$ & $\mathbf{2 0 3 0}$ & $\mathbf{2 0 5 5}$ & $\mathbf{2 0 4 0}$ & $\mathbf{2 0 4 5}$ & $\mathbf{2 0 5 0}$ \\
\hline Utilized Capacity & 5.5 & 7.2 & 9.4 & 12.3 & 16.1 & 21.1 & 27.5 & 36.0 & 47.0 & 61.5 \\
Full Capacity & 12.7 & 16.6 & 21.8 & 28.4 & 37.2 & 48.6 & 63.5 & 83.0 & 108.4 & 141.7 \\
\hline
\end{tabular}

TABLE 6: Energy potential of municipal solid wastes in Nigeria.

\begin{tabular}{lcccccccccc}
\hline Year & $\mathbf{2 0 0 5}$ & $\mathbf{2 0 1 0}$ & $\mathbf{2 0 1 5}$ & $\mathbf{2 0 2 0}$ & $\mathbf{2 0 2 5}$ & $\mathbf{2 0 3 0}$ & $\mathbf{2 0 5 5}$ & $\mathbf{2 0 4 0}$ & $\mathbf{2 0 4 5}$ & $\mathbf{2 0 5 0}$ \\
\hline Population Estimate ('000,000) & 129 & 150 & 165 & 183 & 202 & 226 & 250 & 279 & 306 & 338 \\
MSW estimate ('000,000 tonnes) & 29.7 & 34.5 & 37.9 & 42.1 & 46.4 & 52.0 & 57.5 & 64.2 & 70.4 & 77.7 \\
Energy potential $\left(10^{15} \mathrm{~J}\right)$ & 376.7 & 438.1 & 481.9 & 534.4 & 589.9 & 660.0 & 730.1 & 814.8 & 893.6 & 987.1 \\
\hline
\end{tabular}

Source: ECN [7].

TABLE 7: Total biomass energy potential in Nigeria.

\begin{tabular}{lcccccccccc}
\hline Biomass resource & $\mathbf{2 0 0 5}$ & $\mathbf{2 0 1 0}$ & $\mathbf{2 0 1 5}$ & $\mathbf{2 0 2 0}$ & $\mathbf{2 0 2 5}$ & $\mathbf{2 0 3 0}$ & $\mathbf{2 0 5 5}$ & $\mathbf{2 0 4 0}$ & $\mathbf{2 0 4 5}$ & $\mathbf{2 0 5 0}$ \\
\hline Agro-residue & 1924.2 & 2575 & 3445.9 & 4611.5 & 6171.2 & 8258.4 & 11051.6 & 14789.6 & 19791.8 & 26485.9 \\
Livestock wastes & 152.6 & 199.0 & 261.5 & 346.4 & 462.7 & 623.4 & 847.3 & 1161.6 & 1606.1 & 2239.0 \\
Forest Residue & 5.5 & 7.2 & 9.4 & 12.3 & 16.1 & 21.1 & 27.5 & 36.0 & 47.0 & 61.5 \\
Municipal Solid Wastes & 376.7 & 438.1 & 481.9 & 534.4 & 589.9 & 660.0 & 730.1 & 814.8 & 893.6 & 987.1 \\
\hline TOTAL (PJ) & $\mathbf{2 4 5 9 . 0}$ & $\mathbf{2 3 1 9 . 3}$ & $\mathbf{4 1 9 8 . 7}$ & $\mathbf{5 5 0 4 . 6}$ & $\mathbf{7 2 3 9 . 8 7}$ & $\mathbf{9 5 6 2 . 9}$ & $\mathbf{1 2 6 5 6 . 5}$ & $\mathbf{1 6 8 0 2}$ & $\mathbf{2 2 3 3 8 . 5}$ & $\mathbf{2 9 7 7 3 . 5}$ \\
\hline
\end{tabular}

Source: ECN [7].

of biomass energy in Nigeria, some studies were carried out and Table 4 shows the five-yearly estimate of energy potential of agro-residues which is based on the $6 \%$ annual increase of agricultural produce according to the Central Bank of Nigeria [15]. It is assumed that the increases in annual production of agricultural produce and annual generation of agro-residues are equal. From the table, it is showed that the energy potential in 2020 will be about $4.6 \mathrm{EJ}$ and could rise to about $26.5 \mathrm{EJ}$ in 2050 . It should be pointed out that the major contributors to the potential are fruit and vegetable wastes, sorghum stalks, maize residues, rice residues, and cassava peels which contribute about $60 \%$ of the total annual energy potential.

The quantity of forest residues produced in Nigeria in 1997 and the energy from each waste are shown in Table 3 while the 5-yearly energy potentials of forest residues for full and utilized capacities from 2005 to 2050 are shown in Table 5 using the increase in forest production index. Based on the analysis, it could be inferred that the energy potential of forest residues in 2020 at the current utilized capacity will be about 12.3 PJ and could reach about 62 PJ in 2050. However, at full capacity, the energy potential of forest residues in 2020 will be about 28.4 PJ and may reach 142 PJ in 2050 as depicted in Table 5.

Table 6 presents the population estimates, estimated annual municipal solid wastes generation, and the energy derivable from the wastes. The municipal solid waste, as well as its energy potential, is assumed to increase with increasing population. The energy potential of municipal solid wastes which could be harnessed is about 534.4 PJ in 2020 and may increase to about 987.1 PJ in 2050.

From the potential of biomass energy presented in Table 7 and the energy demand in Nigeria (Table 8), the summary of the results presented in Figure 2 depicts that the total potential of biomass in Nigeria as at 2020 will be about 5.5 EJ and has the potential to increase to about 29.8 EJ by 2050. 
TABLE 8: Total energy demand based on 10\% GDP growth rate (MTOE).

\begin{tabular}{lccccccc}
\hline Item & $\mathbf{2 0 0 5}$ & $\mathbf{2 0 1 0}$ & $\mathbf{2 0 1 5}$ & $\mathbf{2 0 2 0}$ & $\mathbf{2 0 2 5}$ & $\mathbf{2 0 3 0}$ & Average growth rate (\%) \\
\hline Industry & 8.08 & 12.59 & 26.03 & 39.34 & 92.34 & 145.21 & 16.2 \\
Transport & 11.7 & 13.48 & 16.59 & 19.70 & 26.53 & 33.36 & 4.7 \\
Household & 18.82 & 22.42 & 28.01 & 33.60 & 33.94 & 34027 & 2.6 \\
Services & 6.43 & 8.38 & 12.14 & 15.89 & 26.95 & 38.00 & 8.7 \\
\hline TOTAL (PJ) & $\mathbf{4 5 . 0 1}$ & $\mathbf{5 6 . 8 7}$ & $\mathbf{8 2 . 7 7}$ & $\mathbf{1 0 8 . 6 6}$ & $\mathbf{1 7 9 . 7 5}$ & $\mathbf{2 5 0 . 8 4}$ & $\mathbf{8 . 3}$ \\
\hline
\end{tabular}

Source: ECN [7].

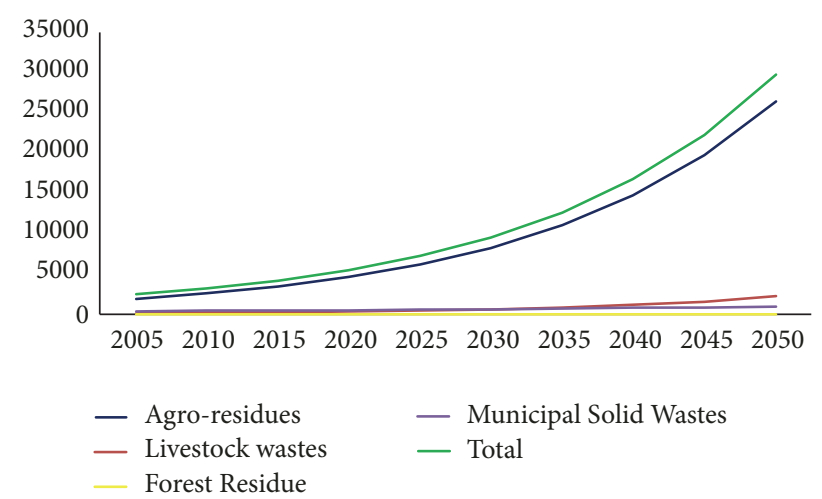

Figure 2: Total annual energy potential of biomass in Nigeria (PJ).

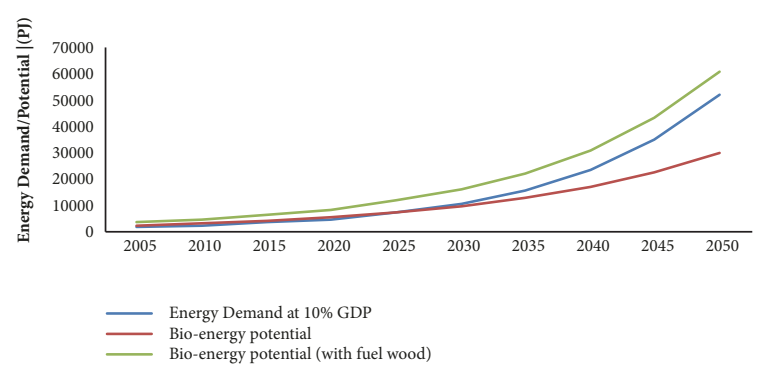

FIgURE 3: Comparison of energy demand at 10\% GDP with the bioenergy potential.

The results show that forest residues contribute the least to the overall annual biomass energy potential. Agro-residues, livestock wastes, and municipal solid wastes together contribute over $99 \%$ of the overall biomass potential in the country. Agro-residues are the largest single contributor to the overall biomass potential producing over $75 \%$ of the total annual energy potential.

Also, using the Model for Analysis Energy Demand (MAED) and Wien Automatic System Planning (WASP) package, the Energy Commission of Nigeria [7] forecasted the demand of energy in Nigeria from 2000 to 2030. The total energy demand by sector, assuming a $10 \%$ Gross Domestic Product growth, is shown in Table 8 . The total annual energy demand has been extrapolated to 2050 assuming the average growth rate of $8.3 \%$. The total energy demand and the total energy potential of biomass are compared in Figure 3. The comparison shows that, with efficient utilization, energy from biomass in the form of agro-residues, livestock wastes, forest residues, and municipal solid wastes have the potential of meeting the energy demand in the short term as seen between 2005 and 2030. Beyond 2030, the energy demand exceeds the bioenergy potential. This may be due to a predicted rapid increase in population or increased industrial activities within the country.

According to Dayo [16], fuelwood has constituted over $60 \%$ of the annual energy consumption between 1990 and 2005. Assuming a continuing trend, the consideration of fuelwood in the estimate of the biomass potential will enhance the possibility of biomass energy in meeting energy demands in Nigeria as shown in Figure 3. However, the use of fuelwood for energetic purposes is being discouraged in Nigeria to prevent deforestation which has a negative effect on the environment. Hence, to suffice the demand for energy while looking away from fuelwood, there will be a need to exploit energy crops which can be cultivated in both arable and grass-lands. The cultivation of energy crops will increase the bioenergy potential. There may also be the need to exploit greatly other forms of renewable energy such as solar, wind, geothermal, ocean, tidal, and wave energy.

With all the enormous potentials of biomass in the country, sadly enough, the direct combustion has been used mainly over the years to obtain energy from the renewable resources. Apart from the huge inherent pollution accompanying this method, the efficiency of this method of utilization is between 5 and $15 \%$ which is rather inefficient [14]. Therefore, other means of conversion should be exploited other than the direct combustion. Also, efficient use of biomass must be assured to be able to utilize the better part of the obtainable bioenergy potential. Moreover, while considering other renewable energy sources, energy policies in the country should also cover the development and modernization of agriculture, investment in infrastructure, and development and commercialization of biomass technologies.

Harnessing the energy available from the renewable resources allows the attainment of notable reductions in the consumption of our finite fossil fuels, pollution levels, and worrying climate changes. The inherent potentials of the renewable energy sources have been displayed in literatures through the techno-economic analysis of the biomass for energy generation [17-44]. Sequel to the technical potential analysis as shown in the previous sections of this work, biomass can be adopted to combat the present energy crisis in Nigeria. Unlike wind or solar energy, biomass-based power generation can be operated on demand. On the technologies of energy conversion from biomass shown in Figure 4, currently, most of the biomass resources in Nigeria are utilized 
TABLE 9: Progress of research and application of bioenergy as fuel in Nigeria.

\begin{tabular}{|c|c|c|c|}
\hline Conversion Route & Research in progress & Domestic Application & Industrial Application \\
\hline Direct Combustion & $\sqrt{ }$ & $\sqrt{ }$ & $x$ \\
\hline Gasification & $\sqrt{ }$ & $x$ & $x$ \\
\hline Pyrolysis & $\sqrt{ }$ & $x$ & $\times$ \\
\hline Anaerobic digestion & $\sqrt{ }$ & $x$ & $\times$ \\
\hline Fermentation & $\sqrt{ }$ & $x$ & $x$ \\
\hline Biodiesel & $\sqrt{ }$ & $\times$ & $x$ \\
\hline
\end{tabular}

\begin{tabular}{|c|c|c|c|}
\hline $\begin{array}{c}\text { Biomass } \\
\text { Resources }\end{array}$ & $\begin{array}{c}\text { Supply } \\
\text { System }\end{array}$ & $\begin{array}{c}\text { Conversion } \\
\text { Processes }\end{array}$ & End Use \\
\hline $\begin{array}{c}\text { Conventional forestry } \\
\text { Short rotation } \\
\text { forest }\end{array}$ & Harvesting & Biochemical & Transportation fuels \\
\hline $\begin{array}{c}\text { Sawmill conversion } \\
\text { products }\end{array}$ & Collection & $\begin{array}{c}\text { Physical / Chemical } \\
\text { Processes } \\
\text { e.g }\end{array}$ & Heat \\
\hline $\begin{array}{c}\text { Agricultural crops } \\
\text { And residue }\end{array}$ & Handling & Deoxygeneration & Electricity \\
\hline $\begin{array}{c}\text { Oil-bearing plants } \\
\text { Dnimal products }\end{array}$ & Delivery & $\begin{array}{c}\text { Deploymerisation } \\
\text { Anids }\end{array}$ & $\begin{array}{c}\text { Renewable } \\
\text { Construction } \\
\text { materials }\end{array}$ \\
\hline $\begin{array}{c}\text { Municipal solid } \\
\text { waste }\end{array}$ & Storage & $\begin{array}{c}\text { Plant based } \\
\text { Pharmaceuticals }\end{array}$ \\
\hline Industry waste & Fermentation & $\begin{array}{c}\text { Renewable } \\
\text { Chemical including } \\
\text { polymers }\end{array}$ \\
\hline
\end{tabular}

FIGURE 4: Biomass conversion technologies, products, and applications. Source: UK Biomass Strategy [3].

by direct combustion mostly in the rural areas. Although progress is being made in other means of biomass conversion as shown in Table 9, the government policies have not seemed to state exactly how to implement and develop the use of bioenergy in the country but have placed more focus on developing and financing conventional energy [14].

From the biomass conversion technology shown above, biomass gasification offers a considerable potential and can act as a key enabling technology for the development of integrated and flexible bioenergy strategies for Nigeria. Also, considering the advantages of biomass gasification technology (conversion of carbon-based feedstock to clean synthetic gas, which is primarily a mixture of hydrogen gas and carbon monoxide as fuels) over other biomass energy conversion technologies shown in Figure 4, accepting the feasibility studies, viability of generating, and meeting the energy needs in Nigeria, it is highly recommended that the imminent energy crisis in Nigeria could be averted by the biomass gasification technology.

\section{Principle of Biomass Gasification Technology}

Gasification is the conversion of combustible solids (e.g., wood, coal, and charcoal) into a gaseous fuel mixture with small quantities of char and condensable compounds. Depending on the production context, the gas may be referred to as "wood gas", "synthesis gas", "producer gas", or "coal gas" to name a few. During gasification of biomass, the material is heated in a reactor called gasifier to a high temperature, which causes a series of physical and chemical changes that result in the evolution of volatile products and carbonaceous solid residues. The amount of volatiles produced and their compositions depend on the reactor temperature, type, and characteristics of fuel material. In this process, the gasifying agent could be air, steam, oxygen, or hydrogen. The energy generated through the system could be used for electrical power generation or production of thermal energy.

The gasification process uses several reactors, which can be classified according to the relative movement of the fuel and the gasifying medium as either fixed beds (updraft, downdraft, and cross-draft) or fluidized beds (bubbling, circulating, spouted, and swirling). In fixed bed gasifiers, the solid fuels move either countercurrent or concurrent to the flow of a gas as reaction takes place, and the solids are converted to gases.

The weight loss (or thermal degradation) in a nitrogen atmosphere occurred in mainly three stages: dehydration (below $125^{\circ} \mathrm{C}$ ), the second stage being active pyrolysis $\left(125-500^{\circ} \mathrm{C}\right)$, and the third stage being passive pyrolysis above $500^{\circ} \mathrm{C}$. In updraft gasifier, the combustion takes place at the bottom of the bed which is the hottest part of the gasifier and product gas exits from the top at lower temperature 
TABLE 10: Advantages and disadvantages of different types of biomass gasifier.

\begin{tabular}{|c|c|c|}
\hline Gasifier Types & Advantages & Disadvantages \\
\hline \multirow{4}{*}{ Updraft } & Mature for heat & Feed size limits \\
\hline & Small scale application & High tar yields \\
\hline & Can handle high moisture & Scale limitations \\
\hline & No carbon in ash & Slagging potential \\
\hline \multirow{4}{*}{ Downdraft } & Small scale application & Feed size limits \\
\hline & Low particulates & Scale limitations \\
\hline & Low tar & Producer gas \\
\hline & & Moisture sensitive \\
\hline \multirow{4}{*}{ Fluid Bed } & Large scale applications & Medium tar yield \\
\hline & Feed characteristics & High particle loading \\
\hline & Direct/indirect heating & \\
\hline & Can produce syngas & \\
\hline \multirow{3}{*}{ Circulating Fluid Bed } & Large scale applications & Medium tar yield \\
\hline & Feed characteristics & High particle loading \\
\hline & Can produce syngas & \\
\hline \multirow{4}{*}{ Entrained Flow } & Can be scaled & Large amount of carrier gas \\
\hline & Potential for low tar & High particle loading \\
\hline & Can produce syngas & Potentially high S/C \\
\hline & & Potential size limit \\
\hline
\end{tabular}

Source: Bain [8].

(around $500^{\circ} \mathrm{C}$ ). In a downdraft gasifier, both the feed and product gas move downward and the product exits from the bottom at a higher temperature, i.e., around $800^{\circ} \mathrm{C}$. Gasification takes place at high temperature in the presence of an oxidizing agent (also called a gasifying agent). Heat is supplied to the gasifier either directly or indirectly which raises the gasification temperature of $600-1,000^{\circ} \mathrm{C}$. However, the gasification temperature needs to be high enough (above $\left.750-800^{\circ} \mathrm{C}\right)$.

It should be stated that the fixed bed gasifiers have distinct reaction zones-drying, pyrolysis, and combustion and gasification which occur simultaneously in the reactor are particularly suited to solid fuels contacting operations that require close temperature control (especially if the temperature is variable along the flow path), carryover of particles away from the reaction zone, simple operation, and minimum erosion of the body of the reactor.

Unlike fixed bed reactors, gasifier models with a fluidized bed have no distinct reaction zones-drying, pyrolysis, and gasification occur simultaneously in the reactor-as the reactor is mixed and, thus, closed to isothermal. Fluidized bed reactors can be classified by configuration and the velocity of the gasifying agent, e.g., bubbling, circulating, spouted, and swirling fluidized beds. Fluidized bed gasifiers have several advantages over other gasification reactors, including strong gas solids contact, excellent heat transfer characteristics, better temperature control, large heat storage capacity, good degree of turbulence, and high volumetric capacity. The disadvantages of fluidized bed reactors are large pressure drop, particle entrainment, and erosion of the reactor body. Due to their complicated and expensive control systems, fluidized bed gasifiers appear to be commercially viable over
$30 \mathrm{MW}$ thermal outputs. The summary of the advantages and the disadvantages of these gasifiers are shown in Table 10.

The schematic diagram of the biomass gasification plant for energy production is shown in Figure 5 while Figure 6 depicts the energy generation potentials of the different types of gasifiers.

It is shown in Figure 6 that the downdraft gasifier is suitable for $1 \mathrm{~kW}$ to $1.2 \mathrm{MW}$ range thermal capacity, whereas updraft is $1.2 \mathrm{MW}$ to $20 \mathrm{MW}$, fluidized-bed gasifier is $1.3 \mathrm{MW}$ to $50 \mathrm{MW}$, circulating fluidized bed is $8 \mathrm{MW}$ to $200 \mathrm{MW}$, and pressure circulating fluidized bed is $70 \mathrm{MW}$ to $1000 \mathrm{MW}$. Although the thermal capacity of cross-draft gasifier is not displayed in the figure, it is well established that crossdraft gasifier is suitable for $10 \mathrm{MW}$ to $200 \mathrm{MW}$ range thermal capacity.

5.1. Applications of Biomass Gasification Technology. The produced gases from biomass gasification contain both combustible and noncombustible gases. The gas can be used in industrial application areas, irrigation, vehicular power, electricity production, direct heating, and production of value added products. Although, at present, biomass technology will be unattractive in the urban areas because of the logistic challenges of transporting biomass to the energy generation sites, the technology has become significantly more attractive in industrial shaft power applications in rural areas where grid electricity is either expensive or unavailable. Currently many fossil-powered units are in use; thus, where the interruption of fossil fuel supply is common, alternative energy sources such as producer gas are being sought. As an alternative to internal combustion engines that use producer gas exclusively, there are engines that are operated on the 


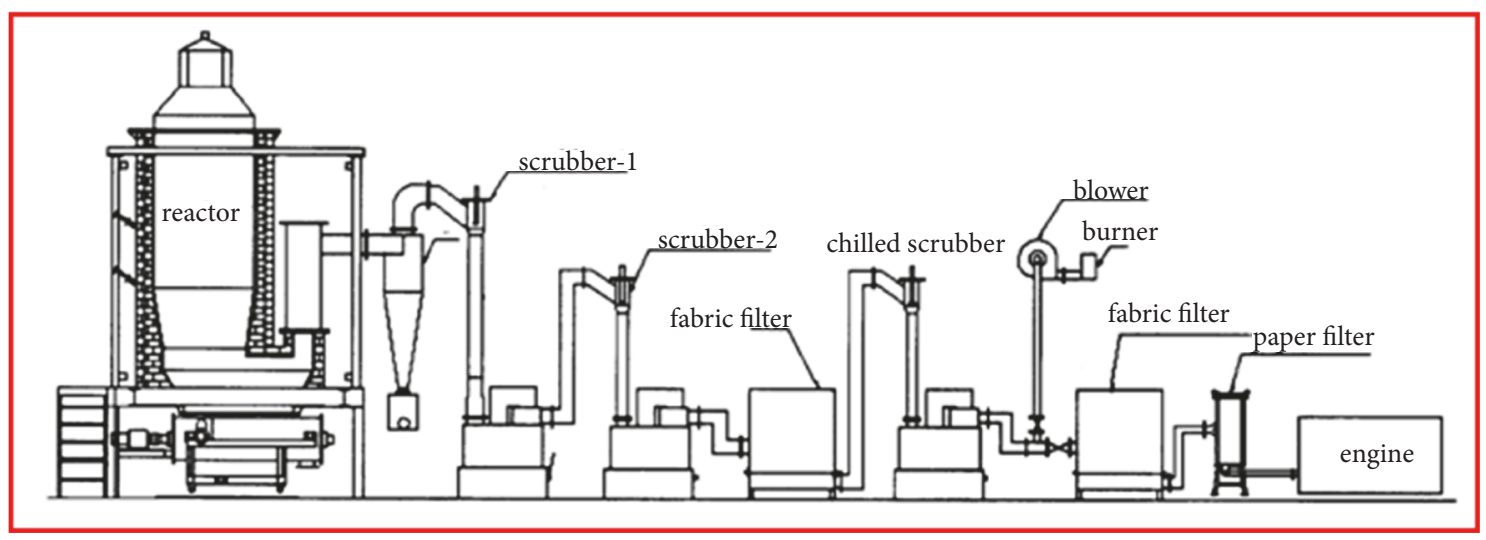

FIGURE 5: Schematic diagram of biomass gasification plant [3].

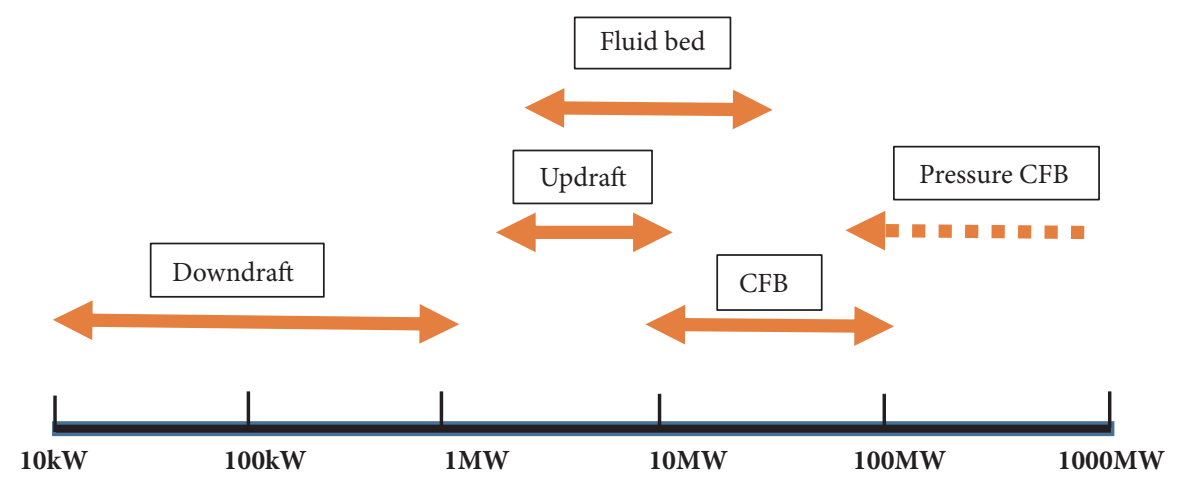

FIGURE 6: Potential energy generation of different gasifiers. Source: UK Biomass Strategy [3]. Thermal: $1 \mathrm{~kg}$ of fossil fuel replaced by $3.5 \mathrm{~kg}$ of biomass. Power: biomass consumption, $1.0-1.4 \mathrm{~kg} / \mathrm{kWh}$.

dual-more principle. In such systems, the producer gas is used as a supplement to diesel fuel. Here the consumption of wood would be approximately $1.4 \mathrm{~kg}$ per $\mathrm{kWh}$ of shaft power. Where the availability of suitable biomass is scarce, the possibility always exists for the cultivation of trees that take approximately three to four years to mature. The possibility of using crop residues in gasifiers has also gained great attention. While the questions about the technical suitability of crop residues as gasifier fuel remained to be answered, the concept shows great promise. The economic and technical problems of using direct heat gasifiers appear to be relatively minor. With more experience and better design, the range of potential uses will expand.

5.2. Advantages of Biomass Gasification Technology. As an advantage of the biomass gasification system compared to conventional combustion technology, the gasifier offers several benefits for converting solid wastes (biomass) into energy. The major benefit of the gasifier project is the reduction of Green House Gases (GHG) emissions. Solid waste is considered a carbon neutral biofuel because it releases equal amount of carbon into the atmosphere as it absorbed during its lifetime (Figure 7). Fossil fuels, on the other hand, increase the amount of carbon releases into the atmosphere because the carbon has been trapped for years.
The development and utilization of biomass gasification system will enhance the reduction in major health risks through reduced air, land, and water pollution. Adverse effects of global warming on weather and climate can be mitigated by reduced $\mathrm{CO}_{2}$ emissions. California Biomass Energy Alliance [45] stated that biomass gasification has twotimes the effectiveness in reducing GHG over other types of renewable technology, or nuclear. The statement buttressed the fact that there will be reduction in health care costs and the impact of likely stricter federal emission standards in the future if biomass gasification technology is adopted in the country. Such a healthy environment achieved by the proper utilization of biomass gasifiers attracts and retains business and also encourages the tourist industry. Small scale industries can benefit by using it, thereby increasing their marginal profit and reducing their down time. Educational institutions can also benefit from the use of the plant since they can run their laboratory equipment on it without erratic or interrupted power supply. It will also give the institution an opportunity to explore, relocate, and train its faculty and students in an emerging environmental technology. Consequently, there will be drastic reduction on the overdependence of petrol and the effects of petroleum scarcity in Nigeria if the technology is properly adopted, supported, and developed. Application of the technology will enhance waste control, nutrient recycling, job creation, use of surplus 


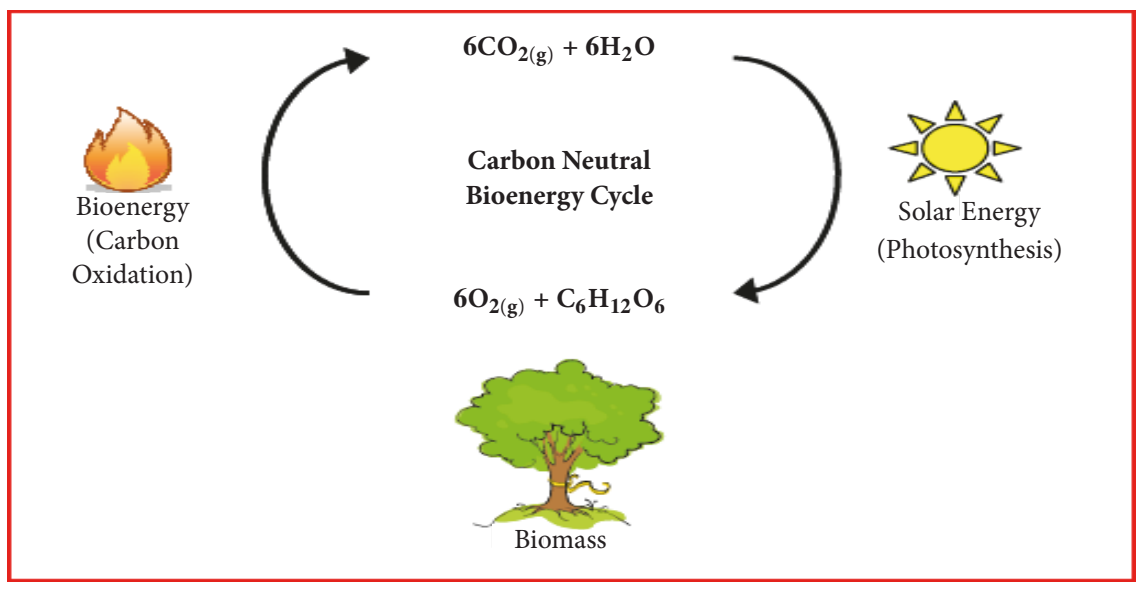

FIGURE 7: Schematic of balanced carbon cycle.

agricultural land, provision of modern energy carriers to rural communities, and improvement of land management.

Amongst the bioenergy technologies, the biomass gasification option for meeting the rural electricity needs of domestic, irrigation, and rural small and cottage industrial as well as thermal activities is shown to have a large potential. Based on the calculation, the unit cost of electricity of using biomass gasification technology for power generation system is comparatively lower than other available bioenergy technologies. On an industrial scale, biomass gasification and power generation systems have been well established. It is an advanced and suitable technology for Remote Village Electrification (RVE) and Village Energy Security Programme (VESP). Therefore, biomass gasification technology has been shown to be an efficient way to utilize waste biomass and the gas produced. Gasification produces less harmful exhaust as biomass is very low in sulfur, chlorine, or heavy metals, which are detrimental to the environment. The biggest advantage of gasification is the use of variety of feedstock and products, as the syngas can also be used for chemical industry along with power generation. Being an agricultural country, Nigeria has strong potential for power generation from agricultural residues. Therefore, there will be continuous supply to the plant.

A $60 \mathrm{MW}$ of the plant can create up to 3,500 sustainable jobs, thereby reducing unemployment and improving the economy of rural areas by empowering farmers and rural dwellers in Nigeria.

The power plants that will demand in excess of 300,000 green tonnes of solid wastes/biomass per annum could produce enough electricity for approximately 30,000 homes for a period of 20 years, based on an average residential consumption of 7.4 MWh per annum. Energy facilities operating on this scale would most likely have an installed capital cost of approximately $\$ 2$ million per MW capacity. To build and commission a $30 \mathrm{MW}$ bioenergy plant, the total cost is estimated as being in the range of $\$ 60$ to $\$ 65$ million [46]. Moreover, this technology has been receiving attention in various parts of the world because it is an environmentally sound technology, possesses a decentralized electricity generation, presents a good use of domestic resources, assists savings in foreign currency in importing energy, gives a boost to agriculture, is easy to operate and maintain, provides local employment, and efficiently replaces the fossil fuels. The disadvantages that come with the utilization can successfully be mitigated by both "good practices" and engineering measures.

Moreover, the fact that the proposed gasification plant has highly efficient process, flexibility in applications over a range of output ratings (five to hundreds of KWs), low initial investment, low cost of power production, better process control and convenience, cleaner combustion in connected equipment, and low maintenance cost gives the technology undeniable advantages over other technologies that use high grade energy generated from fossil fuels [46].

\section{Economic Analysis of Biomass Gasification Technology}

In order to ensure sustained and healthy growth of the biomass power sector in Nigeria, it is necessary to rationally evaluate the cost of energy generation and to determine a selling rate of the generated energy which should be acceptable to consumers and attractive to investors. On carrying out the economic potential of the biomass gasification technology adopting a fluidized bed type in meeting energy needs, Dasappa [47] and Hewitt [4] costs of building biomass gasification plants shown in Table 11 and Figure 8, respectively, were used as the reference points for the economic analysis of the biomass gasification system in Nigeria.

For the success and commercialization of any new technology, it is essential to know whether the technology is economically viable or not. Therefore, an attempt was made to evaluate economics of the biomass gasifier. In the economic analysis, among the various options that exist for checking the fiscal performance of an investment power project, the levelized generation cost (LGC) and the net present value (NPV) are the recommended indicators in the electricity industry for checking the viability of decentralized electricity 
TABLE 11: Cost of building biomass gasification plant.

\begin{tabular}{lcr}
\hline Cost & Potential & \\
\hline Capital cost & Up to 100 kW capacity & $\sim 2000$ USD $/ \mathrm{kW}$ \\
& Beyond 100kW capacity & $\sim 1500 \mathrm{USD} / \mathrm{kW}$ \\
\hline Maintenance cost & Up to 100 kW capacity & $\sim 2.5-3 \mathrm{USD} \mathrm{c} / \mathrm{kWh}$ \\
& Beyond 100kW capacity & $\sim 1.0-2 \mathrm{USD} \mathrm{c} / \mathrm{kWh}$ \\
\hline Operating cost & Fuel cost & $\sim 2.5-3 \mathrm{USD} \mathrm{c} / \mathrm{kWh}$ \\
\hline Power potential & Biomass consumption & $1.0-1.4 \mathrm{~kg} / \mathrm{kWh}$ \\
\hline Thermal energy potential & $1 \mathrm{~kg}$ of fossil fuel replaced by 3.5 kg of biomass \\
\hline
\end{tabular}

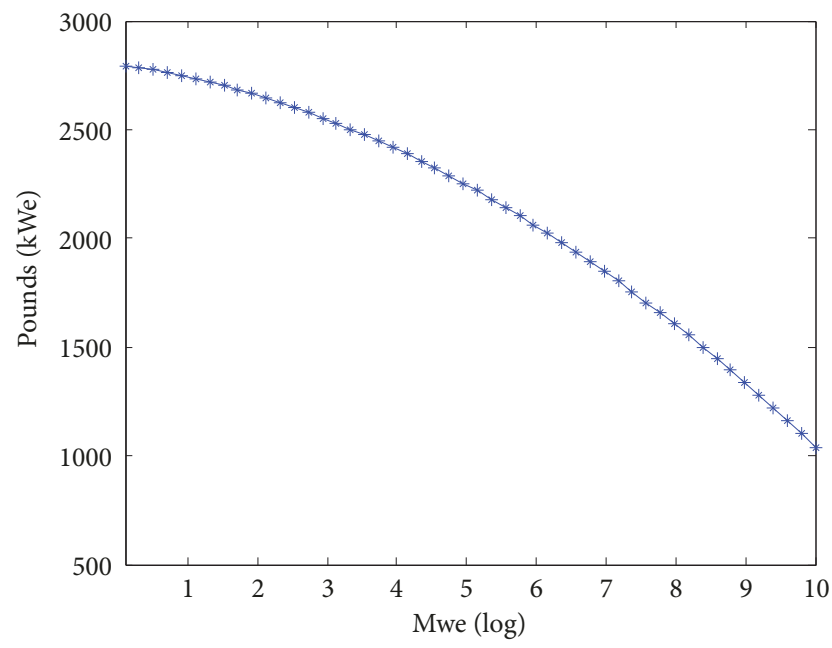

FIGURE 8: Cost of building biomass gasification plant. Source: Hewitt [4].

generation system [48]. The merits and the economic potential and analysis of the biomass gasification technology can be evaluated in terms of the following indices:

(i) Net present value (NPV): the present worth of the entire project.

(ii) Benefit cost ratio (BCR): the benefits from the project which are in proportion with the costs involved.

(iii) Payback period (PBP): the years it will take to get the investment back from the project, i.e., the year in which the net present value of all costs equals the net present value of all benefits. It could also be defined as the minimum period over which the investment for the project is recovered.

(iv) Internal rate of return (IRR): the real return of the project or the maximum rate of interest at which capital can be arranged for the project.

6.1. Techno-Economic Model Assumptions. In the economic analysis, the cost of generation is determined mainly by the following:

(1) Capital investment cost which includes cost of the gasifier, engine generator, civil/construction work and installation, biomass preparation unit, syngas clean-up unit, electricity distribution network, and electrical and piping connection to the site of the gasifier installation.

(2) Operation and maintenance costs which include salaries and wages, cost of repair (including spare parts, water, lubrication, and miscellaneous expenses), fixed cost, fuel cost, cost of catalyst, chemicals and waste disposal, capital depreciation, average income tax, average return on investment, insurance, overhauling equipment cost, cost of administrative offices, storage areas, utilities, and other essential and nonessential auxiliary facilities.

The following models [9, 10, 49-53] are developed and used for the economic analysis of the biomass technology:

(i) Total investment cost is given by

$$
C=C_{G}+C_{P M}+C_{C W}+C_{A}+C_{F}+C_{R}
$$

(ii) Annual amount of electricity $\left(E_{t}\right)$ sent out by the power plant in $\mathrm{kWh}$ net is given by

$$
E_{t}=P_{\text {rated }} \times 8760 C F\left(1-\frac{P_{a u x}}{100}\right)(1-M L F)
$$

(iii) Operating and maintenance cost is given by

$$
\begin{aligned}
M= & K_{G} C_{G}+K_{P M} C_{P M}+K_{C W} C_{C W}+K_{A} C_{A}+K_{F} C_{F} \\
& +K_{R} C_{R}+\left(8760 \times C F \times M p_{n} W_{r}\right)
\end{aligned}
$$

(iv) Annual revenue (AR) from the sale of electricity is given by

$$
A R=\frac{C}{n}\left[\left\{1+m\left(\frac{(1+I)^{n}-1}{I(1+I)^{n}}\right)\right\}\right]
$$

(v) Cost of fuel is given by

$$
C_{F}=8760 \times C F \times P_{\text {rated }} \times C_{B} \times S F C R
$$

(vi) The cost of one kWh of biomass gasification electricity generated is given by

$$
C_{p k W}=\frac{C}{N n}\left[\left(\frac{1}{P_{R} C_{F}}\right)\left\{1+m\left(\frac{(1+I)^{n}-1}{I(1+I)^{n}}\right)\right\}\right]
$$

(vii) Benefit delivered annually by the project is

$$
B_{A}=E_{t} C_{p k W}
$$


TABLE 12: Biomass gasification cost breakdown (2010 US \$).

\begin{tabular}{lcc}
\hline Item & Capital Cost & Proportion of Cost \\
\hline Consultancy/Design & 324.5 & $6 \%$ \\
Civil works & 705.1 & $13 \%$ \\
Fuel Handling/Preparation & 324.5 & $6 \%$ \\
Electrical/balance of plant & 217.0 & $4 \%$ \\
Converter system(gasifier) & 3362.9 & $62 \%$ \\
Prime Mover & 488.2 & $9 \%$ \\
\hline
\end{tabular}

Source: NERC [9].

(viii) The payback period of the project is given by

$$
n=-\frac{\operatorname{In}\left(1-\operatorname{IC} /\left(B_{A}-m C\right)\right)}{\operatorname{In}(1+I)}
$$

(ix) The net present value (NPV) of the project is given by

$$
\begin{aligned}
N P V= & B_{A}\left[\frac{(1+I)^{n}-1}{I(1+I)^{n}}\right] \\
& -\left[C\left\{1+m\left(\frac{(1+I)^{n}-1}{I(1+I)^{n}}\right)\right\}\right]
\end{aligned}
$$

The economic viability is established when the NPV is greater than 0.

(x) The benefit cost ratio (BCR) is given by

$$
B C R=\frac{B_{A}}{C}\left[\frac{\left((1+I)^{n}-1\right) / I(1+I)^{n}}{1+m\left(\left((1+I)^{n}-1\right) / I(1+I)^{n}\right)}\right]
$$

The project is acceptable if $\mathrm{BCR}$ is greater than 1 .

The internal rate of return (IRR) is determined from the following model using numerical methods such as NewtonRaphson:

(xi)

$$
\begin{aligned}
B_{A} & {\left[\frac{(1+I R R)^{n}-1}{\operatorname{IRR}(1+I R R)^{n}}\right] } \\
& =\left[C\left\{1+m\left(\frac{(1+I R R)^{n}-1}{\operatorname{IRR}(1+I R R)^{n}}\right)\right\}\right]
\end{aligned}
$$

(xii) Levelized cost of electricity is

$$
L C O E=\frac{\sum_{t=1}^{N}\left[\left(I_{t}+(1-T)\left(C_{F}+M\right)\right) /(1+d)^{N}\right]}{\sum_{t=1}^{N}\left[E_{t}\left[(1+d)^{n}-1\right] / d(1+d)^{n}\right]}
$$

where

$$
d=\frac{W \times R_{e}}{V}+\frac{X \times R_{d}}{V}(1-T)
$$

6.2. Economic Assumptions and Parameters. The total capital investment cost of the biomass conversion system with all the ancillaries as shown in Table 12 plus allowance for importation and freight charges is estimated by NERC [9] as $4000 \$ / \mathrm{kWh}$. The estimates of percentage share of the various cost components are as shown in Table 12 [10]. The nominal
TABLE 13: Economic parameter for biomass gasification power plant.

\begin{tabular}{lc}
\hline Parameter & Value \\
\hline Investment Cost & $4000 \$ / \mathrm{kW}$ \\
Fixed Operation and Maintenance cost & $56 \$ / \mathrm{kW}-\mathrm{yr}$ \\
Variable Operation and Maintenance cost & $5.17 \$ / \mathrm{kW}-\mathrm{yr}$ \\
Electricity tariff & $0.17 \$ / \mathrm{kW}-\mathrm{yr}$ \\
Fuel Cost & $0.024 \$ / \mathrm{kg}$ \\
Fed Income tax & $32 \%$ \\
Risk free rate & $18 \%$ \\
Capital from debt & $70 \%$ \\
Capital from equity & $30 \%$ \\
Nominal Cost of debt & $24 \%$ \\
Nominal return on equity & $29 \%$ \\
Nominal after tax WACC & $17 \%$ \\
\hline
\end{tabular}

Source: NERC [10].

1 USD $=\mathrm{N} 150$ for the 2010 US \$ (based on the available data).

TABLE 14: Additional economic parameter for biomass gasification power plant.

\begin{tabular}{lc}
\hline Parameter & Percentage of Initial Investment \\
\hline Depreciation & 19 \\
Interest rate & 10 \\
Discount rate & 10 \\
Salvage value & 10 \\
Labour & 10 \\
Repair and Maintenance cost & 3 \\
\hline
\end{tabular}

post tax weighted average cost of capital (WACC) of $17 \%$ as recommended by NERC [9] was used as the discount rate in this study while straight line method over 20 years was used for the plant/equipment depreciation.

The average price of $\mathrm{N} 3$ per $\mathrm{kg}$ (USD 0.025) based on the estimate of the previous study of 2003 [54] escalated to its supposed cost in 2010 USD using inflation rate of $3 \%$ [49]. The other economic parameters used in the analysis presented by NERC [9] are given in Table 13.

Table 14 shows some other parameters used to carry out the economic analysis of the gasification system.

Following the economic parameters given above, the breakdown of the investment cost of the proposed $60 \mathrm{~mW}$ 
TABLE 15: Biomass gasification capital investment cost breakdown.

\begin{tabular}{lr}
\hline Item & Capital Cost (US \$) \\
\hline Consultancy/Design & $16,200,000$ \\
Civil works & $35,100,000$ \\
Fuel Handling/Preparation & $16,200,000$ \\
Electrical, auxiliaries and accessories of plant & $10,800,000$ \\
Converter system(gasifier) & $167,400,000$ \\
Prime Mover (Engine) & $24,300,000$ \\
Capital Investment Cost & $\mathbf{2 7 0 , 0 0 0 , 0 0 0}$ \\
\hline
\end{tabular}

TABLE 16: Estimated cost structure of biomass gasification plant.

\begin{tabular}{lc}
\hline Installed capacity of the Biomass Gasification plant & $60 \mathrm{MW}$ \\
Annual Hour of Operation & 8,000 \\
Life in Years of plant & 20 \\
Biomass in tons dry mass/year & $\$ 270,000,000$ \\
\hline Biomass Gasification System Capital Investment & $\$ 25,650,000$ \\
Interest on value of the machinery and equipment & $\$ 51,300,000$ \\
Depreciation & $\$ 27,000,000$ \\
Annual Labour cost & $\$ 8,100,000$ \\
Annual repair and maintenance cost & $\$ 2,700,000$ \\
Insurance and taxes & $\$ 10,800,000$ \\
Total Biomass cost/year & $\$ 395,550,000$ \\
Total Cost & $170,294,000 \mathrm{kWh}$ \\
Annual Electricity production from the plant & $\$ 0.21$ \\
Cost of kWh of Biomass gasification electricity generated & $\$ 49,443.75$ \\
Cost of operation per hour & $\$ 35,761,824$ \\
Benefit delivered annually & $\$ 304,440,408$ \\
Net Present Value of the benefit & $\$ 347,751,230$ \\
Net Present Value of operation and maintenance cost & $\$ 833,301,230$ \\
Accumulated Net Present Value of all the cost & $\$ 528,860,822$ \\
Net Present Value of the benefit & 0.365 \\
Benefit Cost Ratio &
\end{tabular}

biomass gasification system for decentralized electricity generation is shown in Table 15. Using some economic assumptions and factors [55-57], the estimated cost structure of the biomass gasification system is shown in Table 16.

Based on the recommended cost of USD $0.025 / \mathrm{kg}$, Table 16 shows the estimated cost structure of the gasification power plant project. Although investment in biomass gasification power plant will bring economic dividends to the rural dwellers, the results of the financial analysis reveal that investing in the gasification system for electricity generation in Nigeria areas is not economically viable and profitable as shown in Table 16. The negative net present value of US $\$ 528,860,822$ and the benefit cost ratio that is far less than 1 are financial indicators of a huge financial loss if the cost of electricity generated at US\$ $0.21 / \mathrm{kWh}(\mathrm{N} 35 / \mathrm{kWh})$.

Table 17 depicts the estimated cost structure of the biomass gasification system for electricity generated at levelized generated cost of $\$ 0.5775 / \mathrm{kWh}$ which is almost three times the tariff set by NERC [9]. Although the net present value of the project is positive as shown in the table, it is not advisable and profitable to invest on this project at the given levelized generation cost since the cost benefit ratio indicated unity and the payback period of the project is approximated equal to the life in years of the plant. Moreover, the high levelized generated cost of $\$ 0.5775 / \mathrm{kWh}(\mathrm{N} 96 / \mathrm{kWh}$ ) will be unaffordable by the rural dwellers.

The estimated cost structure of the biomass gasification system with a planned selling price of $\$ 0.727 / \mathrm{kWh}$ is shown in Table 18. From the table, the net present value of the project is positive, the cost benefit ratio is greater than 1 , and the payback period of the project is 10.14 years. These economic indicators established the economic viability of the project at the given cost. However, the selling price of $\$ 0.727 / \mathrm{kWh}(\mathrm{N} 120 / \mathrm{kWh})$ is on the very high side which will not be affordable by the rural dwellers. Since the biomass gasification technology represents the least-choice technology for rural electrification especially where there is no extension of electricity grid [49], the capital investment cost, operation and maintenance cost, and fuel cost should be reduced through development of the gasification system 
TABLE 17: Estimated cost structure of biomass gasification plant.

Installed capacity of the Biomass Gasification plant

Annual Hour of Operation

Life in Years of plant

Biomass in tons dry mass/year

400,000

Biomass Gasification System Capital Investment

Interest on value of the machinery and equipment

$\$ 25,650,000$

Depreciation

$\$ 51,300,000$

Annual Labour cost

$\$ 27,000,000$

Annual repair and maintenance cost

$\$ 8,100,000$

Insurance and taxes

$\$ 2,700,000$

Total Biomass cost/year

$\$ 10,800,000$

Total Cost

$\$ 395,550,000$

Annual Electricity production from the plant

$170,294,000 \mathrm{kWh}$

Cost of operation per hour

$\$ 49,443.75$

Benefit delivered annually

Net Present Value of the benefit

Net Present Value of operation and maintenance cost

Accumulated Net Present Value of all the cost

Net Present Value of the project

Benefit Cost Ratio

Payback period of investment

19.19 years

Internal rate of return

Levelized cost of kWh of gasification electricity generated

Annual revenue from the sale of electricity

TABLE 18: Estimated cost structure of biomass gasification plant.

\begin{tabular}{|c|c|}
\hline Installed capacity of the Biomass Gasification plant & $60 \mathrm{MW}$ \\
\hline Annual Hour of Operation & 8,000 \\
\hline Life in Years of plant & 20 \\
\hline Biomass in tons dry mass/year & 400,000 \\
\hline Biomass Gasification System Capital Investment & $\$ 270,000,000$ \\
\hline Interest on value of the machinery and equipment & $\$ 25,650,000$ \\
\hline Depreciation & $\$ 51,300,000$ \\
\hline Annual Labour cost & $\$ 27,000,000$ \\
\hline Annual repair and maintenance cost & $\$ 8,100,000$ \\
\hline Insurance and taxes & $\$ 2,700,000$ \\
\hline Total Biomass cost/year & $\$ 10,800,000$ \\
\hline Total Cost & $\$ 395,550,000$ \\
\hline Annual Electricity production from the plant & $170,294,000 \mathrm{kWh}$ \\
\hline Cost of operation per hour & $\$ 49,443.75$ \\
\hline Benefit delivered annually & $\$ 123,804,026$ \\
\hline Net Present Value of the benefit & $\$ 1,053,943,697$ \\
\hline Net Present Value of operation and maintenance cost & $\$ 437,751,230$ \\
\hline Accumulated Net Present Value of all the cost & $\$ 833,301,230$ \\
\hline Net Present Value of the project & $\$ 220,642,467$ \\
\hline Benefit Cost Ratio & 1.265 \\
\hline Payback period of investment & 10.14 years \\
\hline Internal rate of return & 17.55 \\
\hline Selling price of kWh of gasification electricity generated & $\$ 0.727$ \\
\hline Annual revenue from the sale of electricity & $\$ 41,666,511$ \\
\hline
\end{tabular}


using local materials, purposeful and efficient plantation of biomass for the energy generation, giving out of financial incentives by the government to the investors, and locating the power plant very close to the source of feedstock generation.

\section{Conclusion}

In this work, the techno-economic potential of biomass gasification technology in Nigeria has been studied and analyzed. From the technical and the economic analyses, the possibility and economic viability of the technology of meeting the present energy crisis in Nigeria are established. The advantages and the various applications of the technology were demonstrated. The disadvantages such as high capital cost and selling price per $\mathrm{kWh}$, standardization of the technology packages with services, and logistics problems that come with the technology could be mitigated with "good practices" and engineering measures. Since the utilization of biomass gasification technology will practically and drastically obviate if not totally eliminate the energy crisis in Nigeria especially in rural areas where there is no extension of electricity grid, it is therefore recommended that the technology should be adopted with reduced capital investment cost, operation and maintenance cost, and fuel cost through development of the gasification system using local materials, purposeful and efficient plantation of biomass for energy generation, giving out of financial incentives by the government to the investors, and locating the power plant very close to the source of feedstock generation. This will reduce the cost of electricity generation and the payback period and it will also encourage the development of the biomass gasification.

\section{Nomenclature}

\begin{tabular}{|c|c|}
\hline AR: & Annual revenue \\
\hline $\mathrm{B}_{\mathrm{A}}$ : & Benefit delivered annually \\
\hline BCR: & Benefit cost ratio \\
\hline C: & Total capital investment cost \\
\hline $\mathrm{C}_{\mathrm{pkW}}:$ & $\begin{array}{l}\text { Cost of kWh of electricity generated from } \\
\text { the biomass gasification plant }\end{array}$ \\
\hline $\mathrm{C}_{\mathrm{A}}$ : & $\begin{array}{l}\text { Cost of electricity, accessories, auxiliaries, } \\
\text { and miscellaneous }\end{array}$ \\
\hline $\mathrm{C}_{\mathrm{B}}:$ & Cost of biomass \\
\hline $\mathrm{C}_{\mathrm{F}}:$ & Cost of fuel (biomass) \\
\hline $\mathrm{C}_{\mathrm{G}}$ : & Cost of gasifier or fuel conversion system \\
\hline $\mathrm{C}_{\mathrm{PM}}:$ & Cost of prime mover \\
\hline $\mathrm{C}_{\mathrm{l}}:$ & Total capital investment of the project \\
\hline $\mathrm{C}_{\mathrm{CW}}:$ & Cost of civil work \\
\hline $\mathrm{C}_{\mathrm{R}}:$ & $\begin{array}{l}\text { Additional costs (labour, repair and } \\
\text { maintenance, building services, stores, } \\
\text { insurance, and taxes costs) }\end{array}$ \\
\hline CF: & Capacity factor \\
\hline $\mathrm{d}:$ & Inflation-adjusted discount rate \\
\hline $\mathrm{E}:$ & $\begin{array}{l}\text { Annual electricity production from the } \\
\text { plant }\end{array}$ \\
\hline $\mathrm{I}_{\mathrm{C}}$ : & Total project investment cost \\
\hline I: & Real rate of return \\
\hline $\mathrm{D}$ & Internal rate of return \\
\hline
\end{tabular}

$\mathrm{K}_{\mathrm{G}}$ : Fraction of the capital cost of biomass gasification power plant used for the operation and maintenance of gasifier

$\mathrm{K}_{\mathrm{PM}}$ : Fraction of the capital cost of biomass gasification power plant used for the operation and maintenance of prime mover (engine)

$\mathrm{K}_{\mathrm{CW}}$ : Fraction of the capital cost of biomass gasification power plant used for the operation and maintenance of engineering and construction work

$\mathrm{K}_{\mathrm{A}}$ : Fraction of the capital cost of biomass gasification power plant used for the operation and maintenance of accessories and miscellaneous

$\mathrm{K}_{\mathrm{F}}$ : $\quad$ Fraction of the capital cost of biomass gasification power plant used for the purchase of fuel and fuel handling

$\mathrm{K}_{\mathrm{R}}$ : $\quad$ Fraction of the capital cost of biomass gasification power plant used for the labour, repair and maintenance, building services, stores, insurance, and taxes

$\mathrm{M}_{\mathrm{Ecp}}$ : Biomass mass conversion potential, $\mathrm{kg} / \mathrm{kWh}$

MLF: Marginal loss factor

$\mathrm{MP}_{\mathrm{n}}$ : Number of manpower required

$\mathrm{m}$ : Percentage of initial investment for annual operating and maintenance costs

N: Annual hour of the plant

$\mathrm{n}$ : Life in years of plant

NPV: Net present value

PBP: Payback period of investment

$\mathrm{P}_{\mathrm{R}}$ : $\quad$ Plant installed capacity

$\mathrm{P}_{\text {aux }}$ : Percentage power consumption by the auxiliaries

$\mathrm{P}_{\text {rated }}$ : Power rated or installed output

$\mathrm{R}_{\mathrm{e}}$ : Nominal cost of debt

$\mathrm{R}_{\mathrm{d}}$ : Nominal cost on equity

SFCR: Specific fuel consumption rate

T: $\quad$ Company tax rate

V: $\quad$ Total market value, $\%$

W: $\quad$ Market value on equity, \%

$\mathrm{W}_{\mathrm{r}}$ : Wage rate for manpower in Nigeria

X: $\quad$ Market value on debt, \%.

\section{Data Availability}

The data used in this work are from National Electric Power Authority [6], Energy Information Administration, EIA Nigeria Energy Data, Statistics and Analysis [2], Energy Commission of Nigeria [7], and Central Bank of Nigeria (2009), "Central Bank of Nigeria Statistical Bulletin", CBN Press, Abuja [15]. The other data can easily be assessed online from various research works cited in this paper or can be available from the corresponding author upon request.

\section{Conflicts of Interest}

The authors declare that there are no conflicts of interest regarding the publication of the present paper. 


\section{Acknowledgments}

The authors acknowledge and appreciate the financial supports received from National Centre for Energy Efficiency and Conservation Energy Commission of Nigeria, Faculty of Engineering, University of Lagos, Nigeria.

\section{References}

[1] Energy Information Administration (EIA), Nigeria Energy Data, Statistics and Analysis - Oil, gas, electricity and coal, Energy Information Administration, 2010.

[2] The Guardian Online, Guardian Newspaper, Nigeria.

[3] UK Biomass Strategy.

[4] N. J. Hewitt, M. Anderson, and M. Novaes, Gasification and Pyrolysis, Center for substainable technologies, University of Ultster, UK, 2008.

[5] T. O. K. Audu and E. O. Aluyor, "Potential of Bioenergy and biofuels technology development in Nigeria," Petroleum Technology Development Journal, vol. 1, pp. 1-7, 2012.

[6] National Electric Power Authority, "Annual Technical Report," Tech. Rep., National Control Centre, Osogbo, Nigeria, 19851992.

[7] Energy Commission of Nigeria (ECN), National energy policy, Energy Commission of Nigeria (ECN), Nigeria.

[8] R. L. Bain, U.S. Department of Energy, Midwest Research Institute, Battelle National Renewable Energy Laboraory.

[9] NERC, "Multi-Year Tariff Order for the Determination of the Cost of Electricity Generation for the Period 1 June 2012 to 31 May 2017," 2012.

[10] International Renewable Energy Agency (1REnA), Renewable Energy Technologies: Cost Analysis Series, vol. 1 of Power Sector Issue 1/5, 2012.

[11] European Commission Joint Research Centre, Yearly average of daily sums of global horizontal irradiation in Nigeria, European Commission Joint Research Centre, 2008.

[12] A. I. Kankara, "Energy-Environment Interactions: Potentials and Problems of Renewable Energy in Nigeria," Advances in Electronic and Electrical Engineering, vol. 3, pp. 25-30, 2013.

[13] B. Aurela, Nigeria and Renewable Energy, Nigeria and Renewable Energy, Finland, 2013.

[14] S. J. Ojolo, J. I. Orisaleye, S. O. Ismail, and S. M. Abolarin, “Technical Potential Of Biomass Energy in Nigeria," Department of Mechanical Engineering, University of Lagos, Akoka, Lagos, Nigeria, 2012.

[15] Central Bank of Nigeria, Central Bank of Nigeria Statistical Bulletin, CBN Press, Abuja, Nigeria, 2009.

[16] F. B. Dayo, "Nigeria Energy Balances: 1990-2005," Tech. Rep., Triple "E" Systems Inc..

[17] D. O. Hall, F. Rosillo-Calle, R. H. Williams, and J. Woods, "Biomass for energy: supply prospects," T. B. Johansson, H. Kelly, and K. N. R. Amulya, Eds., 1993.

[18] M.-L. Cottam and A. V. Bridgwater, "Techno-economic modelling of biomass flash pyrolysis and upgrading systems," Biomass \& Bioenergy, vol. 7, no. 1-6, pp. 267-273, 1994.

[19] C. E. Gregoire and R. L. Bain, "Technoeconomic analysis of the production of biocrude from wood," Biomass \& Bioenergy, vol. 7, no. 1-6, pp. 275-283, 1994.

[20] C. E. Gregoire, "Techno-economic Analysis of the Production of Biocrude from Wood," Tech. Rep. NREL/TP-430-5435, Golden, CO: National Renewable Energy Laboratory, 1992.
[21] Innovative Natural Resource Solutions LLC (INRS), A strategy for increasing the use of woody biomass for energy, National Association of State Foresters, Portland, 2008.

[22] S. O. Jekayinfa and V. Scholz, "Assessment of availability and cost of energetically usable crop residues in Nigeria," in Proceedings of the Conference of international agricultural research for development, Tropentag, University of Kassel-Witzenhausen and University of Göttingen, 2007, in Nigeria, Conference of international agricultural research for development, Tropentag.

[23] D. L. Klass, Biomass for Renewable Energy, Fuels, and Chemicals, Academic Press, San Diego, Calif, USA, 1998.

[24] M. Olise and T. Nria-Dappa, "Overcoming Nigerias Energy Crises: Towards effective utilization of associated gases and renewable energy resources in the Niger Delta," Social Action Briefing, vol. 2, 2009.

[25] E. C. Okoroigwe, N. F. Oparaku, and O. E. Oparaku, Harnessing Nigeria's potential for sustainable economic development, National centre for energy research and development, University of Nigeria, 2008.

[26] O. J. Osaghae, Potential biomass based electricity generation in a rural community in Nigeria, Master thesis, Sustainable energy systems, Department of applied physics and mechanical engineering [Master, thesis], Sustainable energy systems, Department of applied physics and mechanical engineering, Lulea University of Technology, 2009.

[27] A. Rabiu, The cost of electricity in Nigeria, International association for energy economics, First quarter edition, 2009.

[28] A. S. Sambo, Matching energy supply with demand in Nigeria, International Association for energy economics, Fourth quarter edition, 2008.

[29] J. B. Holm-Nielsen, M. Madsen, and P. O. Popiel, "Predicted energy crop potentials for bio-energy world-wide and for EU 25," in Proceedings of the World Bio-energy Conference on Biomass fro Energy, 30th May-1st June, Jonkoping, Sweden, 2006.

[30] J. Schmidhuber, "Impact of an increased biomass use on agricultural markets, prices and food security: A longer-term perspective," in Proceedings of the International symposium of Notre Europe, Paris, 2006.

[31] E. Smeets, A. Faaij, and I. A. Lewandoski, "Quickscan of global bio-energy potentials to 2050 - an analysis of the regional availability of biomass resources for export in relation to underlying factors, Report prepared for NOVEM and Essent," NWS-E-109, Copernicus Institute-Utrecht University, 2004.

[32] U. Arena, F. Di Gregorio, and M. Santonastasi, "A technoeconomic comparison between two design configurations for a small scale, biomass-to-energy gasification based system," Chemical Engineering Journal, vol. 162, no. 2, pp. 580-590, 2010.

[33] L. Wang, C. L. Weller, D. D. Jones, and M. A. Hanna, "Contemporary issues in thermal gasification of biomass and its application to electricity and fuel production," Biomass \& Bioenergy, vol. 32, no. 7, pp. 573-581, 2008.

[34] A. C. Caputo, M. Palumbo, P. M. Pelagagge, and F. Scacchia, "Economics of biomass energy utilization in combustion and gasification plants: Effects of logistic variables," Biomass \& Bioenergy, vol. 28, no. 1, pp. 35-51, 2005.

[35] F. Bruton, Biomass CHP market potential in the Western Region: An assessment, Western Development Commission, WDC, Ireland, 2008.

[36] T. Bolhar-Nordenkampf, C. Proll, H. Aichenig, and Hofbauer., "Techno-Economic Assessment of Combined Heat and Power 
Production from Biomass," in Proceedings of the 2nd world conference and exhibition on biomass, pp. 2015-2018, 2004.

[37] H. Hofbauer and H. Knoef, "Success stories on Biomass Gasification," in Handbook Biomass Gasification, pp. 115-1661, BTG, 2005.

[38] M. N. Islam and F. N. Ani, "Techno-economics of rice husk pyrolysis, conversion with catalytic treatment to produce liquid fuel," Bioresource Technology, vol. 73, no. 1, pp. 67-75, 2000.

[39] H. Mullaney, I. farag, C. LaClaire, and C. Barret, “Technical, Environmemnt and Economic Feasibility of Bio-Oil in New Hampsgire's North Country. Final report," Tech. Rep., Univerity of New Hampshire Chemical Engineering Department, Durham, UK, 2002.

[40] F. K. Kazi, J. Fortaman, R. Aneex et al., "Techno-Economic Analysis of Biochemical Scenarios," Tech. Rep. NREL Report No. TP-6A2-46588.

[41] R. Swanson, A. Planton, J. Satrio, R. Brown, and D. Hsu, "Techno-Economic Analysis of Biomass Gasification scenario," Tech. Rep. NREL Report No. TP-6A2-46587, 2010.

[42] V. P. Saha, R. Kumar, M. Kumar, S. Deswal, and P. Chandna, Techno-Economic and Environmental Analysis of Low Carbon Energy Technologies: Indian Perspectives, Energy Saving Commission WFO, Birmingham, UK, 2012.

[43] F. Trippe, M. Fröhling, F. Schultmann, R. Stahl, and E. Henrich, "Techno-economic assessment of gasification as a process step within biomass-to-liquid (BtL) fuel and chemicals production," Fuel Processing Technology, vol. 92, no. 11, pp. 2169-2184, 2011.

[44] Y. Huang, D. R. McIlveen-Wright, S. Rezvani et al., "Comparative techno-economic analysis of biomass fuelled combined heat and power for commercial buildings," Applied Energy, vol. 112, pp. 518-525, 2013.

[45] "California Biomass Energy Alliance, LLC, BP statistical review of world energy," 2007.

[46] "Renewables Share of Global Electricity Generating Capacity," 2005.

[47] S. Dasappa, "Summary of discussion paper on status, potential and challenges of promoting biomass gasification technologies for industrial applications in Africa," in Proceedings of the First High-level Biofuels Seminar in Africa Addis Ababa, Ethiopia, 2007.

[48] M. Gökçek and M. S. Genç, "Evaluation of electricity generation and energy cost of wind energy conversion systems (WECSs) in Central Turkey," Applied Energy, vol. 86, no. 12, pp. 2731-2739, 2009.

[49] C. Diyoke, S. Idogwu, and U. C. Ngwaka, "An Economic Assessment of Biomass Gasification for Rural Electrification in Nigeria," International Journal of Renewable Energy Technology Research, vol. 3, no. 1, pp. 1-17, 2017.

[50] N. S. Rathore, N. L. Panwar, and V. Y. Chinplunkar, "Design and Techno economic evalution of biomass gasifier for industrial thermal applications," Africa Journal of Environmental Science and Technology, vol. 3, no. 1, pp. 006-012, 2009.

[51] W. Short, D. Packey, and T. Holt, "A manual for the economic evaluation of energy efficiency and renewable energy technologies," Tech. Rep. NREL/TP-462-5173, 1995.

[52] C. M. Bhumralkar, R. L. Mancuso, F. L. Ludwig, and D. S. Renné, "A practical and economic method for estimating wind characteristics at potential wind energy conversion sites," Solar Energy, vol. 25, no. 1, pp. 55-65, 1980.

[53] S. Ahmed, Wind Energy: Theory and Practice, vol. 2nd, PHI Learning Private Limited, New Delhi, India, 2011.
[54] H. Gubja, "Environmental and economic appraisal of power generation capacity expansion in Nigeria," Energy Policy, 2010.

[55] P. Spath, A. Aden, T. Eggeman, M. Ringer, B. Wallace, and J. Jechura, "Biomass Hydrogen Production Detailed Design and Economics Utiltizing the Battelle Columbus Laboratory Indirectly Heated Gasifier," Tech. Rep. NREL/TP-510-37408, National Renewable Energy Laboratory, Golden, CO, 2005.

[56] C. Hamelinck, A. Faaij, H. Denuil, and H. Boerrigter, "Production of FT Transportation Fuels from Biomass; Technical Options, Process Analysis and Optimization and Development Potential," Utrecht University, Netherlands, 2003.

[57] S. Phillips, A. Aden, J. Jechura, D. Dayton, and T. Eggeman, "Thermochemical Design Report: Thermochemical Ethanol via Indirect Gasification and Mixed Alcohol Synthesis of Lignocellulosic Biomass," Tech. Rep. NREL/TP-510-41168, 2007. 

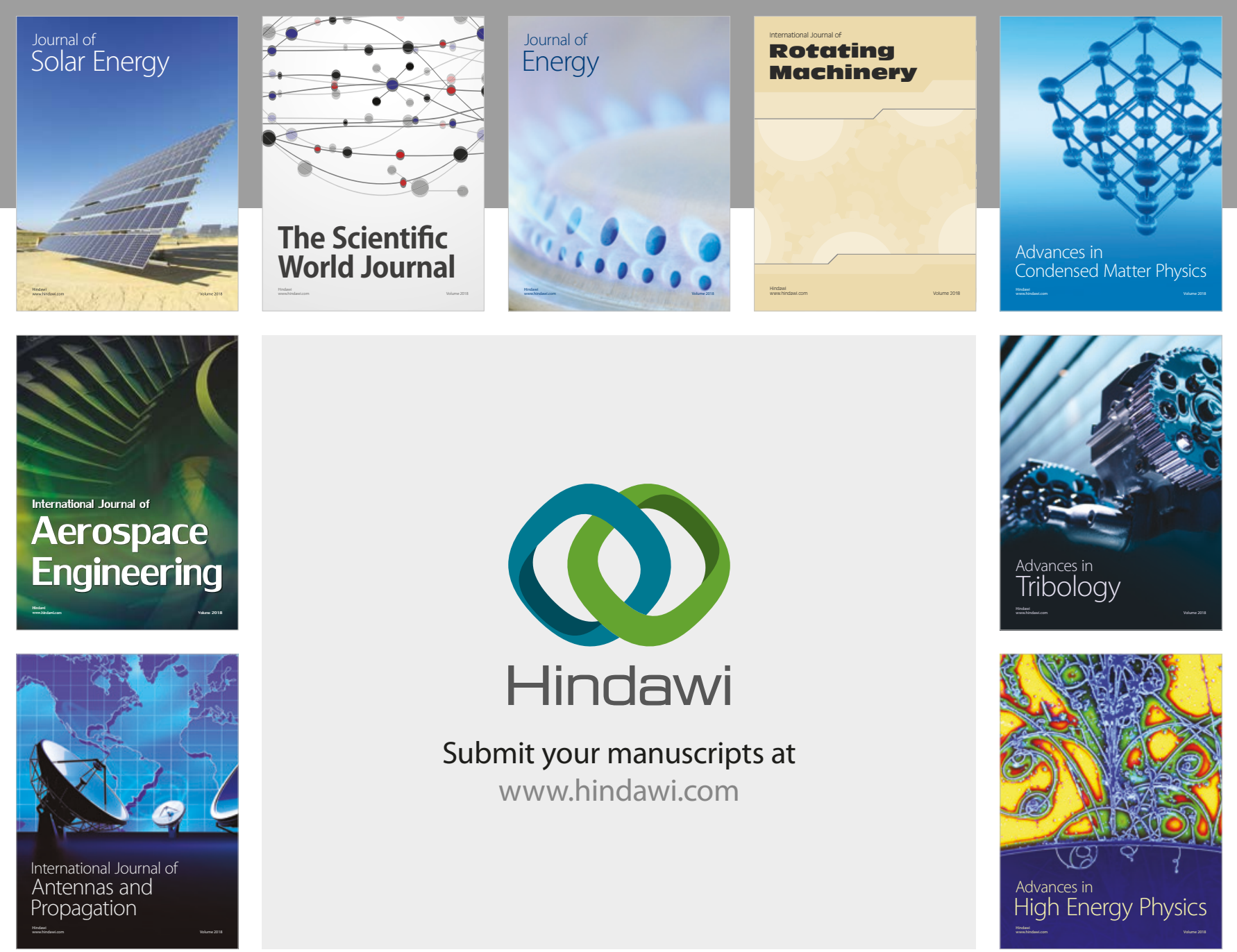

Submit your manuscripts at

www.hindawi.com
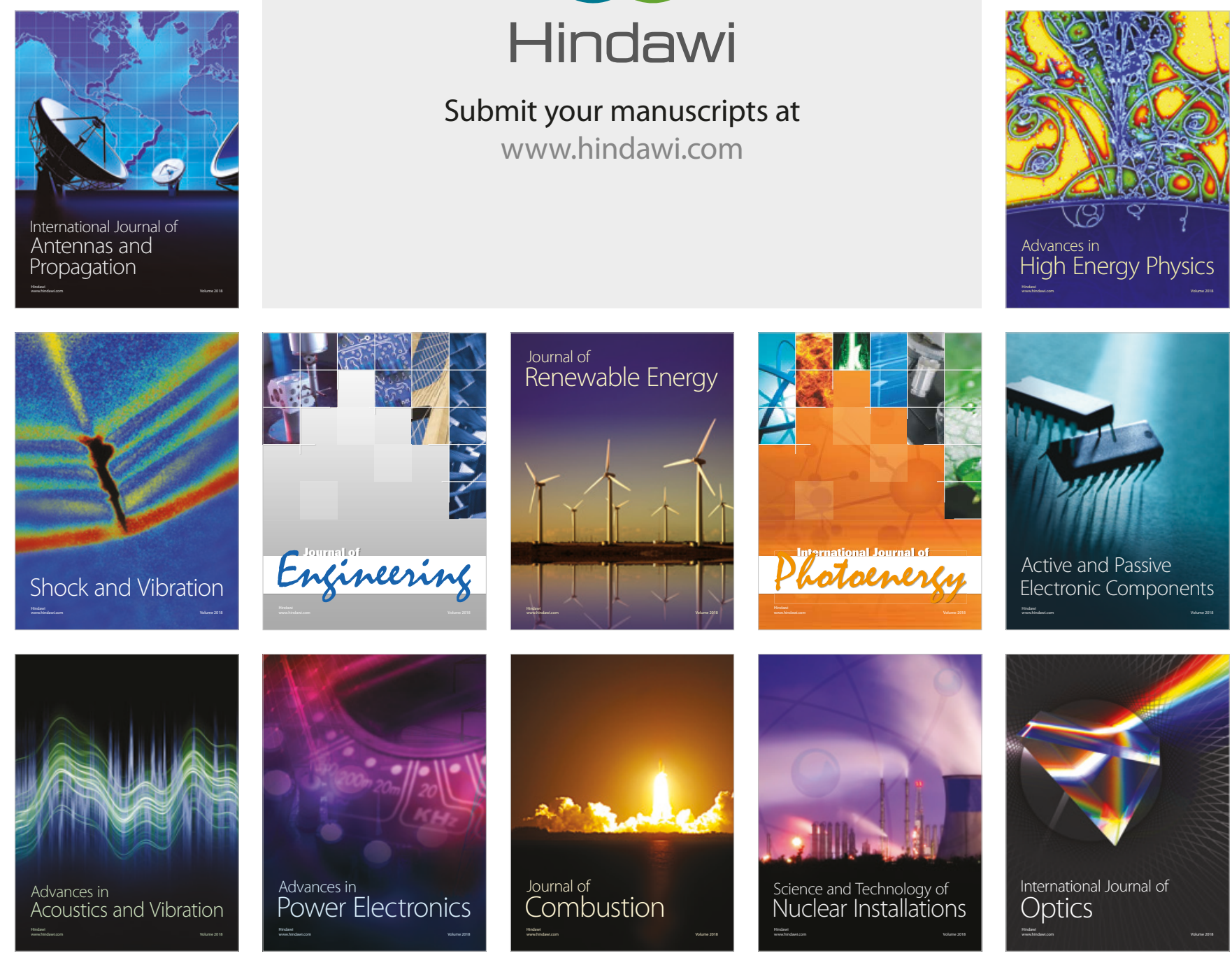